\title{
PROBLEMATIKA PEMBELAJARAN BAHASA INDONESIA BAGI PENUTUR ASING (BIPA) DALAM PERSPEKTIF PSIKOLINGUISTIK
}

\author{
Arlinda Purnamasari \\ arlinda1900003121@webmail.uad.ac.id \\ Pendidikan Bahasa dan Sastra Indonesia \\ Universitas Ahmad Dahlan
}

\begin{abstract}
Abstrak
Pemelajar BIPA biasanya menjadikan bahasa Indonesia sebagai bahasa kedua (B2) atau bahasa ketiganya (B3) sehingga setiap pemelajar memiliki perbedaan bahasa pertama (B1), perbedaan latar belakang sosiokultural, dan perbedaan tujuan mempelajari bahasa Indonesia. Perbedaan tersebut dapat menjadi faktor munculnya problematika dalam pembelajaran BIPA. Tulisan ini akan lebih memfokuskan permasalahan dalam pembelajaran BIPA terutama pada aspek psikolinguistik. Tujuan dilakukannya penelitian ini antara lain: 1) mendeskripsikan pengaruh kurangnya modal kultural pemelajar BIPA tentang Indonesia terhadap pembelajaran BIPA, 2) mendeskripsikan pengaruh kurangnya praktik penggunaan bahasa Indonesia oleh pemelajar BIPA terhadap pembelajaran BIPA, 3) mendeskripsikan pengaruh beban psikologis pemelajar BIPA terhadap pembelajaran BIPA. Penelitian dilakukan menggunakan pendekatan kualitatif dengan metode deskriptif. Data penelitian diperoleh melalui teknik studi pustaka. Berdasarkan problematika yang muncul, pengajar dan pemelajar harus bersinergi mewujudkan proses pembelajaran yang interaktif, inovatif, dan bermakna. Pemelajar harus berusaha beradaptasi dengan keadaan sosiokultural Indonesia. Pengajar dapat memberikan gambaran tentang negara Indonesia karena kejutan budaya dan kejutan bahasa akan menghambat pemerolehan bahasa pemelajar. Selain itu, pemelajar harus terus mempraktikkan kemampuannya dalam berbahasa Indonesia dan berinteraksi secara emosional dengan lingkungan di Indonesia. Pengajar juga harus melihat bahwa kesalahan yang dilakukan pemelajar BIPA merupakan hal yang wajar. Selain itu, pengajar harus terus memberikan afirmasi positif dan motivasi kepada pemelajar.
\end{abstract}

Kata kunci: problematika pembelajaran, bahasa Indonesia bagi penutur asing, psikolinguistik.

\section{PENDAHULUAN}

Kemajuan ilmu pengetahuan dan teknologi, pertumbuhan ekonomi, serta stabilitas sosial politik telah memengaruhi perkembangan globalisasi. Dalam dunia kebahasaan, globalisasi telah memaksa masyarakat untuk menjadi masyarakat bilingual atau multilingual. Masyarakat global beranggapan bahwa menguasai bahasa asing selain bahasa ibu atau bahasa nasionalnya merupakan modal awal untuk hidup di era globalisasi. Ditambah, bahasa merupakan salah satu instrumen diplomasi utama yang berhubungan dengan interaksi mutualisme antarbangsa. Begitu juga dengan bahasa Indonesia, era globalisasi telah menjadikan bahasa Indonesia sebagai salah satu bahasa yang diminati oleh orang-orang di dunia. Posisi Indonesia yang strategis dan perannya di mata internasional menjadikan bahasa Indonesia banyak dilirik oleh masyarakat dunia. Banyak orang asing yang tertarik untuk mempelajari bahasa Indonesia. Melihat peluang tersebut, pemerintah di bawah naungan Badan Pengembangan dan Pembinaan Bahasa mendukung adanya program Bahasa Indonesia bagi Penutur Asing (BIPA). Program BIPA ini diharapkan dapat menaikkan citra positif bangsa Indonesia di mata internasional.

Banyaknya peminat pemelajar asing terhadap bahasa Indonesia dapat dibuktikan, baik di dalam maupun di luar negeri. Berdasarkan data Pusat Pengembangan Strategi dan Diplomasi Kebudayaan (PPSDK), jumlah pemelajar BIPA di kawasan ASEAN periode 2015-2017 diperkirakan sekitar 7.860 pemelajar. Adapun pemelajar selain dari kawasan ASEAN sekitar 6.266 pemelajar. PPSDK juga telah melebihi target kerja sama dengan lembaga penyelenggara BIPA di luar negeri dengan jumlah sekitar 69 lembaga di berbagai negara sasaran. Data 
tersebut diperoleh berdasarkan laporan fisik 88 pengajar BIPA yang diterima PPSDK selama kurun waktu tersebut (Handoko, 2019: 22). Berdasarkan data tersebut terlihat bahwa minat pemelajar asing terhadap bahasa Indonesia cukup tinggi. Para pemelajar BIPA biasanya menjadikan bahasa Indonesia sebagai bahasa kedua (B2) atau bahasa ketiga (B3) mereka. Akibatnya, para pemelajar BIPA memiliki perbedaan bahasa pertama (B1), latar belakang sosiokultural, dan perbedaan tujuan mempelajari bahasa Indonesia. Perbedaan-perbedaan tersebut dapat memunculkan berbagai problematika dalam pembelajaran BIPA.

Pada aspek psikolinguistik, pemerolehan bahasa dan pengajaran bahasa merupakan dua hal yang berbeda. Pemerolehan bahasa lebih mengacu pada internalisasi kompetensi linguistik secara alami. Sedangkan pengajaran atau pembelajaran merupakan proses internalisasi kompetensi linguistik yang dilakukan secara sadar dan hasil dari situasi belajar formal. Dapat disimpulkan bahwa konteks pemerolehan lebih bersifat alami, sedangkan konteks pengajaran lebih bersifat terprogram dan mengacu pada kondisi formal. Berdasarkan hal tersebut, Bahasa Indonesia bagi Penutur Asing (BIPA) merupakan proses yang dipandang melalui pemerolehan dan pengajaran. Selain berada di kelas, pemelajar dapat meningkatkan kemampuan berbahasa Indonesia melalui berinteraksi secara emosional dengan lingkungan di Indonesia. Akan tetapi, kurangnya motivasi dan rasa malu yang dimiliki pemelajar akan menghambat proses interaksi secara emosional sehingga kemampuan berbahasa pemelajar tidak meningkat. Hal tersebut dapat menjadi problematika dalam pembelajaran Bahasa Indonesia bagi Penutur Asing (BIPA).

Dalam penelitiannya, Nastiti (2019: 2) menyebutkan bahwa hambatan dalam pengajaran BIPA terletak pada hambatan standar pembelajaran, hambatan pemelajar, hambatan pengajar, hambatan prasarana dan sarana, hambatan lembaga sasaran, hambatan lingkungan di luar negeri, hambatan administrasi luar negeri, dan hambatan koordinasi antarlembaga. Sejalan dengan hal tersebut, Kusuma (2017: 100) menjelaskan bahwa belum adanya kurikulum BIPA yang dijadikan standar pembelajaran di Indonesia menimbulkan kebimbangan bagi para penyelenggara BIPA. Akhirnya, setiap penyelenggara BIPA memiliki kurikulum yang berbeda. Padahal program kegiatan pembelajaran yang terstruktur menentukan keberhasilan penguasaan keterampilan berbahasa pemelajar. Latupapua (2020: 239) menguraikan bahwa buku ajar dapat menjadi permasalahan dalam pembelajaran BIPA. Buku Sahabatku Indonesia telah menyajikan materi-materi untuk mencapai kompetensi yang telah terstandar dengan baik dan dijadikan acuan dalam pembelajaran BIPA di Indonesia maupun di luar negeri. Akan tetapi, buku tersebut disusun dengan kecenderungan berdasarkan konteks budaya di pulau Jawa dan hanya sedikit porsi tentang budaya di Indonesia Timur.

Penelitian-penelitian tersebut menunjukkan bahwa problematika-problematika dalam pembelajaran BIPA masih terlihat dan memerlukan kajian mendalam. Terlebih, kajian tentang problematika pembelajaran BIPA berdasarkan aspek psikolinguistik belum dikaji secara utuh dan mendalam. Oleh karena itu, penelitian ini akan lebih memfokuskan problematika dalam pembelajaran BIPA dalam aspek psikolinguistik. Sehubungan dengan pemaparan sebelumnya, permasalahan yang akan dibahas pada penelitian ini antara lain, 1) pengaruh kurangnya modal kultural pemelajar BIPA tentang Indonesia terhadap pembelajaran BIPA, 2) pengaruh kurangnya praktik penggunaan bahasa Indonesia oleh pemelajar BIPA terhadap pembelajaran BIPA, 3) pengaruh beban psikologis pemelajar BIPA terhadap pembelajaran BIPA. Sesuai dengan rumusan masalah tersebut, tujuan penelitian ini adalah 1) mendeskripsikan pengaruh kurangnya modal kultural pemelajar BIPA tentang Indonesia terhadap pembelajaran BIPA, 2) 
mendeskripsikan pengaruh kurangnya praktik penggunaan bahasa Indonesia oleh pemelajar BIPA terhadap pembelajaran BIPA, 3) mendeskripsikan pengaruh beban psikologis pemelajar BIPA terhadap pembelajaran BIPA. Penelitian ini memberikan manfaat, baik secara teoretis maupun praktis. Secara teoretis, penelitian ini dapat memberikan sumbangan ilmu pengetahuan dalam bidang ke-BIPA-an dan linguistik, terutama dalam mendeskripsikan problematika yang muncul pada pembelajaran BIPA berdasarkan aspek psikolinguistik. Selain itu, penelitian ini dapat digunakan untuk melengkapi penelitian sebelumnya dan acuan penelitian selanjutnya yang relevan dengan penelitian ini. Secara praktis, penelitian ini dapat digunakan pengajar BIPA untuk mengatasi permasalahan-permasalahan saat mengajar BIPA. Dengan penelitian ini, pengajar diharapkan mampu mengembangkan sistem pembelajaran yang meningkatkan kemampuan berbahasa pemelajar secara optimal.

\section{LANDASAN TEORI}

\section{Hakikat Psikolinguistik}

Berdasarkan segi bahasa, psikolinguistik berasal dari dua kata yaitu psikologi dan linguistik. Meskipun keduanya merupakan dua ilmu yang berlainan, keduanya menaruh perhatian besar terhadap bahasa. Secara umum, linguistik merupakan ilmu yang mengkaji tentang bahasa. Dalam konteks linguistik, bahasa dipandang sebagai sistem bunyi yang arbitrer, konvensional, dan digunakan untuk sarana komunikasi. Mulanya, istilah yang digunakan untuk psikolinguistik adalah linguistic psychology (psikologi linguistik). Ada pula yang menyebutkan psychology of language (psikologi bahasa). Kemudian lahirlah nama psikolinguistik sebagai perkembangan kajian linguistik dan hasil kerja sama yang lebih terarah. Psikolinguistik merupakan ilmu yang menguraikan proses-proses psikologis yang terjadi apabila seseorang menghasilkan kalimat dan memahami kalimat yang didengarnya saat berkomunikasi, serta menjelaskan kemampuan berbahasa yang diperoleh manusia (Simanjuntak, 1987: 1). Darjowijojo (2010) menjelaskan bahwa psikolinguistik adalah ilmu yang mempelajari tahapantahapan dari proses mental yang telah dialami manusia dalam proses berbahasa. Tujuan utama seorang psikolinguis adalah menemukan struktur dan proses yang melandasi kemampuan manusia untuk berbicara dan memahami bahasa. Untuk itu, psikolinguistik membatasi bidang kajiannya, yaitu studi tentang bahasa dan pikiran.

Darjowidjojo (2010) menguraikan empat topik utama dalam mempelajari psikolinguistik, antara lain:

a. Komprehensi, yaitu proses mental yang dialami manusia dalam memahami dan menerima sesuatu saat orang lain mengucapkan sesuatu.

b. Produksi, yaitu proses mental dalam diri seseorang sehingga dapat berujar seperti yang diujarkan orang lain.

c. Manusia dapat berbahasa karena landasan biologis dan neurologis.

d. Pemerolehan bahasa, yaitu cara anak memperoleh bahasa mereka.

Secara teoretis, psikolinguistik memiliki tujuan utama untuk menemukan satu teori tentang bahasa yang paling tepat berdasarkan sisi linguistiknya dan berdasarkan sisi psikologinya yaitu mampu menjelaskan hakikat bahasa serta pemerolehannya. Secara praktis, psikolinguistik mencoba mengaplikasikan pengetahuan linguistik dan psikologi pada masalah seperti, pengajaran dan pembelajaran bahasa, pengajaran membaca permulaan dan membaca lanjut, kedwibahasaan, penyakit bertutur, serta permasalahan sosial lain yang berhubungan 
dengan bahasa, seperti bahasa dan pendidikan, bahasa dan hubungannya dengan pembangunan bangsa.

2. Pemerolehan Bahasa Kedua

Bahasa kedua (B2) merupakan bahasa yang dipakai dan digunakan seseorang ketika mereka telah memperoleh bahasa pertamanya. Pemerolehan bahasa kedua (B2) merupakan proses kompleks yang mencakup berbagai faktor penentu. Kemampuanan bahasa kedua ini mengacu pada pembelajaran. Kemampuanan bahasa kedua berwujud pada kegiatan mengajarkan dan umumnya terjadi pada ruang kelas formal. Tarigan (1988: 125) menyebutkan tiga ciri proses pembelajaran B2:

a. Pemelajar bahasa adalah manusia. Oleh karena itu, di dalamnya terjadi interaksi sosial antar individu (pengajar dan pemelajar) dan berlaku hukum-hukum sosial.

b. Pembelajaran berlangsung dalam interaksi yang dinamis sehingga pemelajar dapat tumbuh dan berkembang menuju ke kedewasaan. Untuk itu, dalam proses pembelajaran pengajar diharapkan memberikan segala pengalamannya agar membantu pemelajar mencapai tujuannya.

c. Pembelajaran berlangsung dalam suasana responsif. Proses pembelajaran merupakan kesempatan besar pemelajar untuk memberikan respons. Pengajar atau sesama pemelajar dapat memberikan pancingan-pancingan sehingga tercapai pembelajaran yang responsif.

Dalam proses pemerolehan bahasa kedua (B2) pemelajar harus menyadari untuk meningkatkan kompetensinya setiap saat. Pemelajar harus menyadari imbalan yang diperoleh apabila dapat menguasai bahasa keduanya. Kesadaran inilah yang akan meningkatkan motivasi untuk menguasai bahasa kedua. Kemampuan bahasa kedua umumnya didorong oleh motivasi instrumental, seperti nilai baik, menghindari rasa malu, dan lainnya. Ahli menyebutkan bahwa motivasi internal akan sangat menentukan keberhasilan menguasai bahasa kedua.

Terdapat faktor-faktor penentu keberhasilan pemerolehan bahasa kedua, antara lain:

a. Faktor lingkungan bahasa

Lingkungan bahasa merupakan semua aspek kebahasaan mencakup visualisasi bahasa dan penggunaan bahasa di lingkungan bahasa sekitarnya.

\section{b. Faktor internal}

Faktor internal meliputi umur, kepribadian, dan motivasi.

Pemerolehan bahasa, sebagaimana pembelajaran bahasa, dapat dilihat berdasarkan beberapa teori yang dikemukakan pakar linguistik. Berikut merupakan beberapa teori pemerolehan bahasa kedua:

\section{a. Teori akulturasi}

Akulturasi merupakan proses penyesuaian diri terhadap kebudayaan baru. Akulturasi dipandang sebagai sesuatu yang penting dalam pemerolehan bahasa kedua. Hal tersebut disebabkan karena bahasa merupakan ekspresi budaya paling nyata dan dapat diamati. Selain itu, kemampuan bahasa baru akan terlihat dari cara pandang masyarakat pemelajar dan masyarakat bahasa sasaran. Pengaruh hubungan akulturasi dan kemampuan bahasa kedua ditentukan oleh jarak sosial dan jarak psikologis pemelajar dengan budaya bahasa keduanya. Jarak sosial merupakan akibat dari faktor-faktor yang mempengaruhi pemelajar sebagai anggota kelompok sosial dalam berhubungan dengan kelompok bahasa sasaran. Jarak psikologis merupakan akibat dari berbagai faktor afektif yang berkaitan dengan pemelajar sebagai individu. Dalam hal ini, faktor sosial memiliki pengaruh utama. Sedangkan faktor psikologis akan berperan pada kasus yang tidak dapat ditentukan oleh jarak sosial. 
b. Teori akomodasi

Sebagaimana teori akulturasi, teori akomodasi juga mencari hubungan antara kelompok sosial pembelajaran dan masyarakat bahasa sasaran. Bedanya, teori akomodasi lebih menjelaskan hubungan dengan bantuan jarak sosial yang teramati. Sedangkan teori akulturasi menjelaskan hubungan dengan variabel yang menciptakan jarak sosial faktual. Teori akomodasi menganggap bahwa hubungan antara kelompok sosial pembelajaran dan masyarakat bahasa sasaran merupakan hubungan yang dinamis sesuai perubahan pandangan terhadap kelompok lainnya. Dalam teori akomodasi, motivasi merupakan hal yang cukup penting. Tingkat motivasi merupakan refleksi dari cara pemelajar secara individual membatasi dirinya dalam hubungan etnis. Melalui motivasi, bahasa secara informal akan lebih mudah diserap dan diperhatikan oleh pemelajar bahasa kedua. Sebaliknya, pemelajar yang kurang memiliki motivasi akan menggantungkan keberhasilan kemampuanan bahasa keduanya pada intelegensi dan bakat semata. Hal tersebut terjadi karena pemelajar kurang mengambil manfaat dari konteks-konteks kemampuanan informal.

c. Teori wacana

Berdasarkan teori wacana, perkembangan bahasa harus dilihat dari cara pemelajar menemukan makna potensial bahasa melalui keikutsertaannya dalam berkomunikasi. Pandangan mengenai peran komunikasi dalam kemampuanan B2 dikenal dengan teori wacana. Terdapat beberapa prinsip dalam teori wacana, antara lain 1) kemampuan bahasa kedua mengikuti urutan alamiah dalam perkembangan sintaksis, 2) penutur asli akan menyesuaikan ujarannya untuk menyatukan makna dengan penutur non asli, 3) strategi percakapan menggunakan makna negosiasi (makna yang disepakati) dan masukan yang teratur. Hal penting dalam teori wacana adalah interaksi sosial dapat memberi pemelajar data terbaik untuk diolah otak, sehingga melalui data tersebut disusun model masukan yang layak dan relevan.

d. Teori monitor

Alat berbahasa dalam teori monitor adalah otak manusia. Dalam mempelajari bahasa, otak dapat menyunting ataupun menyulih bahasa yang telah dihasilkan melalui proses kerja otak dan ditampilkan dalam bentuk performansi verbal bahasa. Berdasarkan teori ini, terdapat tiga aspek yang mempengaruhi penggunaan monitor. Pertama, memerlukan waktu. Apabila memiliki waktu yang cukup, penutur akan memiliki kesempatan berpikir dan menerapkan kaidah gramatikal. Kedua, monitor akan aktif apabila bentuk dan ketepatan bahasa merupakan hal penting bagi penutur. Ketiga, monitor mencerminkan aplikasi pengetahuan bahasa pada perilaku berbahasa seseorang. Monitor merupakan sarana yang digunakan pemelajar untuk menyunting performansi bahasanya. Monitor bekerja menggunakan pengetahuan pemelajar atau kompetensi yang dipelajari. Monitor juga memodifikasi ujaran yang diturunkan dari kompetensi yang diperoleh. Teori monitor memiliki lima hipotesis, antara lain:

1) Hipotesis pemerolehan pembelajaran

2) Hipotesis urutan alamiah

3) Hipotesis monitor

4) Hipotesis masukan

5) Hipotesis saringan afektif

e. Teori kompetensi variabel

Teori ini muncul didasarkan pada pemikiran bahwa kemampuanan bahasa kedua dapat direfleksikan dari bahasa itu digunakan. Produk bahasa terdiri atas produk terencana dan 
tidak terencana. Produk terencana merupakan produk yang dipikirkan terlebih dahulu sebelum diekspresikan. Sedangkan produk tidak terencana merupakan produk yang tidak melalui pemikiran mendalam sebelum diekspresikan. Berdasarkan teori kompetensi variabel, hasil pembelajaran atau pemerolehan bahasa terdiri atas: menirukan ulang bahasa, baik dalam cerita, analog, ataupun dialog; serta bahasa yang dipakai sehari-hari.

f. Teori neurofungsional

Premis dasar teori neurofungsional terhadap kemampuanan bahasa kedua adalah hubungan antara bahasa dengan anatomi saraf. Berdasarkan teori neurofungsional, pemerolehan bahasa kedua terdapat pada wilayah ekspresif verbal maupun area pemahaman secara komprehensif. Pertimbangan-pertimbangan neurofungsional terhadap pemerolehan bahasa kedua menyangkut peran dua belah otak, yaitu hemisfer kanan dan hemisfer kiri atau yang dikenal dengan daerah Wernickle dan daerah Broca.

g. Teori hipotesis universal

Universalitas atau kesemestaan bahasa sangat berpengaruh pada pemerolehan bahasa, baik bahasa pertama atau bahasa kedua pemelajar. Teori ini memiliki dua keunggulan, antara lain:

1) Memusatkan perhatian pada hakikat bahasa sasaran (B2).

2) Menyajikan pertimbangan ulang mengenai transfer bahasa sebagai faktor penting dalam kemampuanan B2.

\section{HASIL PENELITIAN DAN PEMBAHASAN}

Bahasa Indonesia bagi Penutur Asing (BIPA) merupakan suatu proses yang dapat dipandang melalui pemerolehan dan pengajaran. Pemerolehan BIPA berarti bahasa bahasa Indonesia dilakukan oleh warga asing secara alami, tanpa melalui proses belajar secara formal dan terpogram. Berbeda dengan pemerolehan, pengajaran BIPA berarti bahasa Indonesia diperoleh secara sadar dan merupakan proses belajar secara formal. Dalam setiap pembelajaran pasti akan ditemukan berbagai macam permasalahan, termasuk dalam pembelajaran BIPA. Beberapa permasalahan yang dapat ditemukan dalam pembelajaran BIPA, antara lain kurangnya modal kultural pemelajar terhadap budaya bahasa sasaran (bahasa Indonesia), kurangnya praktik penggunaan bahasa Indonesia oleh pemelajar BIPA, dan beban psikologis yang dialami pemelajar BIPA saat menggunakan bahasa Indonesia. Berikut merupakan deskripsi pengaruh permasalahan tersebut dalam pembelajaran BIPA.

1. Modal kultural dan pembelajaran BIPA

Berdasarkan teori akulturasi Schuman, keberhasilan proses pembelajaran BIPA ditentukan oleh tingkat akulturasi masing-masing pemelajar. Teori akulturasi menempatkan bahasa sebagai ekspresi kultural yang paling nyata dan dapat diamati. Akulturasi ini berkaitan dengan kefamilian pemelajar terhadap budaya masyarakat bahasa sasaran, dalam hal ini bahasa Indonesia. Semakin pemelajar asing mengenal budaya bahasa sasaran (bahasa Indonesia), maka keberhasilan proses pembelajaran BIPA juga akan semakin meningkat. Sebaliknya, semakin pemelajar asing tidak familiar dengan budaya Indonesia, tingkat keberhasilan pembelajaran BIPA juga semakin rendah.

Modal kultural yang dimiliki pemelajar BIPA juga akan memengaruhi proses pembelajaran BIPA. Apabila pemelajar memiliki pengetahuan dan pemahaman terhadap budaya Indonesia, proses interaksi dengan masyarakat bahasa sasaran (bahasa Indonesia) menjadi semakin efektif. Namun, apabila pemelajar tidak memiliki bekal kultural yang memadai maka proses interaksi dengan masyarakat Indonesia akan berjalan kaku. Hal tersebut terjadi karena 
pemelajar asing masih menanggung beban psikologis dalam dirinya. Dapat disimpulkan bahwa semakin tinggi kemampuan beradaptasi pemelajar BIPA, semakin tinggi pula keberhasilan proses pembelajaran BIPA. Pemelajar harus dapat meminimalisir kejutan budaya dan kejutan bahasa dalam mempelajari bahasa sasaran (bahasa Indonesia). Hal tersebut disebabkan karena kejutan budaya dan kejutan bahasa dapat menjadi kendala dalam mempelajari dan menguasai bahasa asing.

Berpedoman pada teori akulturasi Schuman, proses pembelajaran BIPA berada dalam situasi yang baik apabila:

a) Pemelajar BIPA berada pada masyarakat tutur dengan tingkat sosial yang sama.

b) Pemelajar BIPA terdorong untuk berakulturasi dengan masyarakat bahasa sasaran (bahasa Indonesia).

c) Budaya bahasa pertama (B1) pemelajar tidak mendominasi.

d) Masyarakat tutur bahasa pertama (B1) dan masyarakat tutur bahasa kedua (B2) saling memiliki sikap positif.

\section{Keaktifan pemelajar BIPA}

Menurut teori akomodasi, motivasi memiliki peran yang penting. Motivasi berpengaruh pada penyerapan pajanan informal oleh pemelajar BIPA. Tingginya motivasi akan membuat pemelajar BIPA mendapat masukan bahasa secara formal melalui pendidikan dan secara informal melalui pajanan. Akan tetapi, pemelajar yang memiliki motivasi rendah hanya akan menggantungkan pada intelegensi dan bakat. Rendahnya motivasi membuat pemelajar kurang mengambil manfaat dari konteks-konteks informal. Dalam hal ini pengajar BIPA seharusnya berbicara menggunakan bahasa Indonesia ketika bertemu pemelajar BIPA dan mengajar di kelas. Semakin aktif pemelajar BIPA mempraktikkan bahasa Indonesia, semakin cepat pula proses pemerolehan bahasa Indonesia.

Proses pembelajaran BIPA mengacu pada teori monitor Krashen, dapat menggunakan dua strategi yaitu strategi pemerolehan dan strategi pembelajaran. Menurut Krashen, strategi pemerolehan bahasa merupakan proses internalisasi kompetensi bahasa sasaran yang identik dengan mengembangkan kemampuan pemelajar melalui proses yang tidak disadari. Proses ini dilakukan hingga pemelajar memiliki kesadaran untuk berinteraksi secara emosional dengan lingkungannya. Konsep pemerolehan tersebut tidak terjadi dalam konteks formal dan klasikal. Melihat strategi pemerolehan, pemelajar BIPA akan menguasai bahasa Indonesia jika berinteraksi dan berkomunikasi secara langsung dengan penutur bahasa Indonesia serta menggunakan media bahasa Indonesia. Komunikasi tersebut tidak ditujukan untuk belajar formal dan klasikal, tetapi untuk memenuhi kebutuhan hidupnya. Untuk itu, komunikasi dan interaksi harus dilakukan secara berkesinambungan tanpa perlu merasa takut ditertawakan mitra tutur karena bahasa yang digunakan tidak sesuai dengan aturan bahasa Indonesia.

Konsep pemerolehan tersebut menuntut pemelajar BIPA untuk menuturkan dan mengekspresikan dirinya secara percaya diri. Awalnya, pemelajar dapat mengekspresikan melalui bahasa isyarat. Kemudian mitra tutur dapat merespons menggunakan bahasa Indonesia. Apabila kegiatan tersebut dilakukan secara terus-menerus dan berkesinambungan, kemampuan pemelajar dalam berbahasa Indonesia dapat terasah. Secara keseluruhan, pemelajar BIPA dapat memperoleh bahasa keduanya melalui sebuah proses yang berulang dan berkesinambungan. 
3. Beban psikologis pemelajar BIPA

Berdasarkan teori monitor Krashen, konsep pembelajaran bahasa secara formal hanya memiliki manfaat terbatas. Pembelajaran di kelas hanya digunakan untuk memonitor, mengontrol, dan memperbaiki kompetensi penguasaan bahasa. Kompetensi berbicara merupakan kompetensi yang didapat melalui pemerolehan bahasa, bukan pembelajaran dalam kelas. Secara psikologis, jika pemelajar terlalu fokus pada pemonitor maka bahasa yang diperoleh cenderung kaku atau tersendat-sendat. Namun, apabila pemelajar tidak terlalu memperhatikan pemonitor maka penguasaan bahasa sasaran akan terhambat. Untuk memperoleh hasil maksimal, pemelajar harus menggunakan monitor secara proporsional dan seimbang. Pemelajar harus menggunakan kompetensi linguistik yang didapat melalui pembelajaran formal dan informal sebagai pelengkap dalam proses pemerolehan bahasa sasarannya.

Sikap pemelajar merupakan faktor penting dalam proses pembelajaran BIPA. Dalam hipotesis saringan afeksi, pemelajar yang memiliki sikap positif dan pengajar yang mampu menciptakan kondisi kelas efektif, akan membuat proses pembelajaran bahasa berjalan maksimal. Sikap pemelajar yang positif akan berpengaruh pada proses pembelajaran BIPA. Sikap positif ini dapat ditandai dengan kepercayaan diri dan motivasi tinggi. Apabila pemelajar memiliki sikap tersebut, rasa malu, khawatir, dan takut salah saat menggunakan bahasa Indonesia akan relatif rendah. Sebaliknya, apabila pemelajar tidak memiliki sikap positif, proses pemerolehan bahasa tidak akan maksimal. Hal ini disebabkan beban psikologis yang dimiliki pemelajar, menghambat pemelajar berinteraksi menggunakan bahasa Indonesia. Dalam pembelajaran bahasa, hal terpenting yang harus dilakukan pemelajar adalah berani untuk berkomunikasi dan berinteraksi menggunakan bahasa Indonesia. Pemelajar juga harus bertarung melawan beban psikologis yang terdapat dalam dirinya, seperti rasa takut, khawatir, malu, dan ragu-ragu dalam menggunakan bahasa Indonesia.

Selain pemelajar, pengajar BIPA juga berpengaruh dalam menumbuhkan sikap positif pemelajar. Pengajar BIPA yang baik harus mampu memberikan motivasi dan inspirasi kepada pemelajar agar mereka terus bersemangat mempelajari bahasa Indonesia. Kesalahan-kesalahan pemelajar ketika mempelajari bahasa Indonesia harus dipandang sebagai hal yang wajar. Pengajar justru harus memperbaiki kesalahan tersebut dan terus memberikan afirmasi positif kepada pemelajar. Selain itu, pengajar BIPA dengan kompetensi yang baik merupakan pengajar yang memiliki pengetahuan ketatabahasaan dan pengetahuan didaktik-metodik, serta pengetahuan komunikasi lintas budaya. Pengetahuan lintas budaya yang dimiliki pengajar mampu mengurangi dampak kejutan budaya dan kejutan bahasa bagi pemelajar BIPA. Pemelajar BIPA merupakan pemelajar dengan latar belakang sosial, budaya, dan bahasa yang beragam sehingga setiap pemelajar memiliki masukan yang berbeda-beda. Masukan yang beragam ini perlu disikapi dengan baik agar menghasilkan output pemelajar yang optimal. Oleh karena itu, pengajar juga harus memperhatikan tujuan pemelajar menguasai bahasa Indonesia. Perbedaan tujuan inilah yang akan membuat pemelajar mendapatkan materi yang berbeda. Contohnya, materi pemelajar dengan tujuan berwisata akan berbeda dengan tujuan pemelajar yang bekerja. Selain itu, pengajar dapat menggunakannya dalam menyusun kurikulum, metode, dan strategi pembelajaran BIPA. 


\section{SIMPULAN}

Perkembangan globalisasi telah memaksa masyarakat dunia menjadi masyarakat yang bilingual atau multilingual. Banyak masyarakat global yang tertarik untuk mempelajari bahasa Indonesia. Dewasa ini, banyak lembaga-lembaga pendidikan di Indonesia dan luar negeri, baik formal atau non formal yang memfasilitasi program pembelajaran bahasa Indonesia bagi penutur asing (BIPA).

Dalam konteks psikolinguistik, pengajaran dan pemerolehan bahasa merupakan dua hal yang berbeda. Konteks pengajaran merupakan sesuatu yang mengacu pada kondisi formal dan terencana. Sedangkan pemerolehan lebih berada pada kondisi alami. Teori akulturasi Schuman menekankan bahwa proses pembelajaran BIPA ditentukan oleh tingkat akulturasi pemelajar. Semakin pemelajar mengenal budaya bahasa sasaran (bahasa Indonesia), maka keberhasilan proses pembelajaran BIPA akan semakin meningkat. Modal kultural yang dimiliki pemelajar juga memengaruhi efektivitas keberhasilan interaksi dengan masyarakat. Semakin pemelajar mengetahui budaya Indonesia, proses interaksi dengan masyarakat Indonesia akan semakin efektif. Selain itu, motivasi pemelajar berperan penting dalam proses pembelajaran BIPA. Semakin tinggi motivasi yang dimiliki pemelajar akan membuat mereka mengambil manfaat berdasarkan konteks informal. Motivasi ini juga berpengaruh pada keaktifan pemelajar dalam berinteraksi menggunakan bahasa Indonesia.

Mengacu pada teori Krashen, pemerolehan bahasa tidak terjadi secara formal dan klasikal tetapi untuk memenuhi kebutuhan hidupnya. Untuk itu, pemelajar BIPA harus aktif berinteraksi dan berkomunikasi menggunakan bahasa Indonesia. Pemelajar harus percaya diri dalam mengekspresikan dan menuturkan maksudnya menggunakan bahasa Indonesia. Apabila kegiatan tersebut terus dilakukan secara berkesinambungan, pemerolehan bahasa kedua pemelajar akan semakin cepat.

Berdasarkan hipotesis saringan afeksi, pemelajar dan pengajar yang mampu bersinergi secara positif akan membuat proses pembelajaran berjalan maksimal. Sikap positif ini akan mempercepat pemerolehan bahasa kedua pemelajar. Oleh karena itu, pemelajar harus menghilangkan beban psikologis dalam dirinya, seperti rasa malu, khawatir, dan takut salah. Beban psikologis ini nantinya hanya akan menghambat proses pemerolehan bahasa kedua pemelajar. Pengajar juga berpengaruh dalam menumbuhkan sikap positif tersebut. Pengajar harus terus memberikan motivasi agar pemelajar bersemangat mempelajari bahasa Indonesia. Pengajar juga perlu memiliki pengetahuan lintas budaya untuk mengatasi kejutan budaya yang akan dialami pemelajar.

Untuk mendukung kelancaran pembelajaran BIPA, kurikulum pengajaran BIPA harus memberikan ruang yang cukup luas agar pemelajar cepat beradaptasi dengan budaya bangsa Indonesia. Selain itu, pemelajar juga akan semakin cepat memposisikan diri sesuai normanorma masyarakat Indonesia. Kurikulum yang disusun juga harus memperhatikan faktor psikologis pemelajar agar pemelajar tidak mengalami goncangan bahasa dan kemunduran motivasi.

\section{DAFTAR PUSTAKA}

Amanat, Tri. 2019. Pemetaan Situasi dan Kondisi Kebahasaan dalam Mendukung

Keberhasilan Program BIPA di Timor Leste. Jurnal Bahasa Indonesia Bagi Penutur Asing. 1(1): 41-52. 
Halimah, Yulianeta, dan Sri Ulina Br Sembiring. 2020. Sastra Bandingan Sebagai Alternatif Bahan Ajar dalam Pembelajaran Bahasa Indonesia Bagi Penutur Asing (BIPA). Prosiding Seminar Internasional Riksa Bahasa: Bahasa dan Sastra Indonesia dalam Perspektif Pendidikan. Pembelajaran, dan Penelitian. 57-66.

Harras, Kholid dan Andhika Dutha Bachari. 2009. Dasar-Dasar Psikolinguistik. Universitas Pendidikan Indonesia: UPI Press.

Kusuma, Emy Rizta dan Asri Ismail. 2017. Karut-Marut dalam Kurikulum Pembelajaran

Bahasa Indonesia Bagi Penutur Asing (BIPA) di Indonesia. Prosiding Seminar Nasional: Bahasa dan Sastra Indonesia dalam Konteks Global. 99-104.

Latupapua, Falantino Eryk. 2020. Mencari Formula Bahan Ajar yang Ramah Budaya Lokal: Problematika Pembelajaran BIPA di Maluku. Arbitrer Jurnal Pendidikan Bahasa dan Sastra Indonesia. 2(1): 233-244.

Maharani, Tisa dan Endang Setiyo Astuti. 2018. Pemerolehan Bahasa Kedua dan Pengajaran Bahasa dalam Pembelajaran BIPA. Jurnal Bahasa Lingua Scientia. 10(1): 121-142.

Nastiti, dkk. 2019. Hambatan dalam Upaya Pengembangan BIPA di Luar Negeri. Jurnal Bahasa Indonesia Bagi Penutur Asing. 1(1): 1-10.

Sudarwati, Emy, Widya Caterine, dan Nia Budiana. 2017. Pengantar Psikolinguistik. Universitas Brawijaya: UB Press. 